\title{
Critiquing 'islandness' as immunity to COVID-19: A case exploration of the Grenada, Carriacou and Petite Martinique archipelago in the Caribbean region
}

\author{
John N. Telesford \\ T. A. Marryshow Community College, Grenada \\ Institute of Island Studies, University of Prince Edward Island, Canada \\ john.telesford@yahoo.com
}

\begin{abstract}
Can mitigation of the spread and transmission of COVID-19 cases on islands, especially in the Caribbean, be attributed to the fact that they are just that: islands? As the corona crisis escalated in 2020, island authorities initially were able to keep COVID-19 cases low and mitigate their spread by implementing unprecedented actions, foremost among them border closures. However, as the realities of economic stresses surfaced, due to the decline in tourism, especially in the Caribbean, the need to balance COVID-19 spread and economic propriety posed a challenge. In this regard, the corona crisis illuminated spatial notions of islandness: boundedness, smallness, isolation and fragmentation. This perspective essay explores islandness in the context of the actions taken in the case study tri-island state of Grenada, Carriacou and Petite Martinique. Being a tri-island state, the nuances of islandness, experienced in an archipelagic context (an archipelago within the Caribbean archipelago) are emphasized. The paper chronicles the measures, issues and challenges of the case islands during the period between 13 March 2020 and 30 January 2021 and juxtaposes them against other actions in other countries and theories of islandness. It is hoped that this paper will contribute to and champion the field of island studies, especially within the Caribbean region.
\end{abstract}

Keywords: archipelago, Caribbean, corona crisis, COVID-19, Grenada, islandness, Small Island Developing States (SIDS)

https://doi.org/10.24043/isj.155 • Received June 2020, accepted February 2021

(C) Island Studies Journal, 2021

\section{Introduction}

On 11 March 2020, the World Health Organization declared the severe acute respiratory syndrome coronavirus 2 (SARS-CoV-2), which causes the coronavirus disease (COVID-19), a pandemic, noting its "alarming level of spread and severity" (WHO, 2020, March 11). The corona crisis was established and has since wreaked global havoc. By 26 January 2021, global confirmed cases and deaths stood at over 93 million and 2 million respectively (WHO, 2021). The trajectory of increase in confirmed COVID-19 cases and deaths also occurred in the Caribbean region where the first cases were reported on 1 March 2020 (Andrus et al, 2020; 
CARPHA, 2020, March 4; Escobedo et al, 2020; Murphy et al, 2020). On 26 January 2021, confirmed cases and deaths in the Caribbean region were approximately 400,000 and 6,000 respectively (CARPHA, 2021, January 28).

In the initial stages of the pandemic, islands in the Caribbean region, described in this essay, 'as a piece or pieces of land completely surrounded by water, regardless of size and population', including states, subnational jurisdictions and archipelagoes, appeared to have kept case numbers low and curbed the transmission and spread of the disease. To achieve this, authorities implemented unprecedented measures, including border closures and controls and social distancing. But the resultant decline in economic activities, due mainly to the decline in travel and tourism (Sheller, 2020), soon posed the challenge of balancing mitigation of disease spread and the need to ease economic pressures (Gourinchas, 2020).

Drawing on the advice of the WHO, and using familiar collaborative mechanisms among organizations such as the CARICOM (Caribbean Community) Secretariat, Caribbean Public Health Agency (CARPHA) and Caribbean Disaster Emergency Management Agency (CEDEMA), Caribbean island authorities acted swiftly to implement non-pharmaceutical interventions (NPIs) vis-à-vis: border closures, social distancing and testing, to contain the importation, transmission and spread of COVID-19 (see e.g. Murphy et al., 2020; Hambleton, Jeyaseelan, and Murphy, 2020). The concept of social distancing, which was relatively new, is described as:

an action intended to reduce contact with other individuals; social distancing measures comprise one category of non-pharmaceutical countermeasures [interventions] (NPC or NPI) aimed at reducing disease transmission and thereby also reducing pressure on health services" (ECDC, 2020, p. 2).

Ferguson et al. (2020) proposed that mitigation and suppression were having a profound impact on global transmission of COVID-19. However, Murphy et al. (2020, p. 4) identified three categories of NPIs instituted in the Caribbean countries in the early stages of COVID19: "control of movement into country, control of gatherings, and then control of movement in country."

But the economic fallout of such measures began to materialize. As Caribbean islands depend heavily on travel and tourism for economic growth and provision of jobs (WTTC, 2018), the pressures of the restrictions began to squeeze inwards as tourism inflows halted (ECLAC, 2020; WTTC, 2020). According to the ECLAC (2020, p. 15) report:

In the Caribbean the most specialized subregion on tourism, this activity had come to a standstill in April [...] Moreover, most ports and airports have been closed to prevent the entry of visitors with COVID-19. As a result, tourism arrivals have dropped to almost zero, and hotels and resorts have witnessed massive closure.

Caribbean islands were in a dilemma, as they grappled to contain COVID-19 and restart their economies.

This paper will attempt to analyze and synthesize this dilemma through the lens of islandness from four spatial perspectives: boundedness, isolation, smallness and fragmentation. In other words, it will seek to find answers to the question: can the mitigation of the spread 
and transmission of COVID-19 cases on islands, especially in the Caribbean, be attributed to the fact that they are just that: islands? The paper therefore attempts to interrogate to what extent islandness has impacted case numbers in the Caribbean in general and in the case island of Grenada in particular, thereby illuminating whether islandness has promoted immunity to negative impacts from COVID-19. The next section presents theoretical perspectives on islandness. The section that follows considers the Caribbean situation and chronicles key actions and measures in the case study island, Grenada. This analysis illuminates islandness by juxtaposing events in the Caribbean region, the case island, and other comparative countries against spatial notions of islandness. A summary of key points and future research concludes the paper.

\section{A theoretical perspective on islandness}

In the field of island studies, the idea/concept of islandness appears to be taking precedence over the ubiquitously used description of islands as 'insular'. According to Royle and Brinklow (2018, p. 11), "Islandness is meant to embody the essence of island living, the attributes that make an island what it fundamentally is, and which it has by necessity, without which it loses that identity." Islandness therefore, promotes a more optimistic and realistic representation of island life. Baldacchino (2018, p. xxv) suggests "that islandness, the emergent distinctiveness or essence of islands, can be translated into distinguishing patterns of spatial development," vis-à-vis: "boundness, smallness, isolation and fragmentation". Randall (2021, p. 100) concludes: "Islandness is associated with a sense of place and belonging that connects people and communities with their natural and social surroundings in tangible and intangible ways." A theoretical perspective of each of these spatial notions is presented to provide a foundation for the paper.

\section{Boundedness}

Geographical boundedness may be the most significant defining feature of islands, making them much easier to control and to manage (Baldacchino, 2018) while providing a sense of safety and protection from intruders/outsiders. In many islands, especially smaller islands, these perimeters can be traversed in short time. This clear boundary certainly conjures a feeling of being trapped within geographical as well as psychological and societal boundaries, which contributes to a strong sense of attachment to one's island (Royle \& Brinklow, 2018). Boundedness provides islands with easily managed border controls through air and sea ports only.

\section{Isolation}

Proximity to other lands, whether a continent or other island, is a key consideration for judging isolation. The Eurostat posits that "an island is not an island, if it is less than one kilometer from the mainland" (Baldacchino, 2018, pp. xxviii). If one were to apply this variable to the Caribbean region, then many islands would be considered isolated from the North American and South American mainlands. However, from a more realistic perspective, isolation may not be a fundamental feature of the Caribbean region, as Caribbean islands are effectively connected to each other by the sea and to the North American mainland, mainly by air travel. Travel and trade between the Caribbean islands and the continent are only restricted by the availability and cost of flights and ferries and freight costs, respectively. 
On the flip side of isolation is connectedness, which epitomizes the adapted cliché: 'no island is an island, no island stands alone'. In a world of islands, therefore, it is necessary for islands to be connected so as to allow islanders to escape the island, to import and export goods and services and to network with other colleagues and friends. In the case of the latter, connectivity via the internet plays a critical role. Baldacchino (2018, p. xxviii) summarizes: "Effective connectivity is critical to isolated islands and their populations."

\section{Smallness}

There is no apparent agreement on what is a small island, although variables such as population, landmass and economic power have been proposed (Baldacchino, 2018, p. xxvi). Notwithstanding this challenge, population and landmass and their manifestation in population densities tend to exacerbate the interaction between islanders and their spaces. In this regard, Baldacchino (2018, p. xxviii) notes: "As islands tend towards smallness [...] their land area tends towards being exclusively coastal"; moreover, "There may be no hinterland to speak of; obligating islanders to interact deeply and intimately with any encroaching party" (Baldacchino, 2020, p. xxviii) and among themselves.

\section{Fragmentation}

During the 2010s, the archipelago has emerged as a focus of study within island studies (e.g. Baldacchino, 2016, 2013; Pugh, 2012; Stratford et al, 2011). Baldacchino (2018, p. xxix) points out that:

We may say islands', but we often really mean 'archipelagos', a set of islands that represent a fragmentation of the domestic space. Indeed, a careful scrutiny of the world's islands reveals that most are actually members of archipelagos, assemblages that range from a minimum size of two [...] to over 50,000 in the archipelago sea off South-West Finland.

Boundedness, smallness, isolation and fragmentation to a lesser degree shape societal islandness, which is at the crux of islandness. They therefore combine to provide a deeper analytical perspective of islands. In this regard, Baldacchino (2018, p. xxv), points out that these "space-related variables [...] and their various and inter-related combinations and permutations $[\ldots]$ provide us with the materialistic renditions of what islands are, and what they can be." From this holistic perspective, can islandness be said to have provided immunity to COVID-19 or, rather, to have contributed to relatively low case numbers and mitigation of spread?

\section{Personal note and methods}

This perspective paper is an exploration of a case study by the author, a Grenadian and Caribbean Islander who has travelled widely throughout the Caribbean and lived through, observed and chronicled some of the measures and possible societal impacts of the corona crisis in Grenada and other Caribbean states and territories. Using a similar approach to Baldacchino (2020), the author drew on experiences in the Caribbean and specifically with Grenada, Carriacou and Petite Martinique. Supported by relevant literature and official global 
and local document reviews, the author takes a snapshot between 13 March 2020 and 26 January 2021 of the unfolding measures and associated issues and challenges in the case island, which may have reflected the actions taken in many Caribbean islands in general. An attempt was made to juxtapose these measures against the theories of islandness, further analyzing and illuminating the arguments associated with the theories, while addressing the proposed question of how islandness may have resulted in the low caseloads in Caribbean islands. The first draft of the paper was done while the author was in a 24 hour, seven days a week curfew and was presented at the first Global Island Studies Webinar in June 2020. It is hoped that this paper will contribute to and champion the field of island studies, especially within the Caribbean region.

\section{Regional COVID-19 situations}

The first case of COVID-19 presented in the Caribbean region on 1 March 2020 (Andrus et al, 2020; CARPHA, 2020, March 4; Escobedo et al, 2020; Murphy 2020 et al, 2020). On 11 March 2020, the Caribbean Public Health Agency (CARPHA, 2020, March 20), reported 17 cases in only six Caribbean states and territories, with two deaths, representing a mere $1.8 \%$ of cases in the Americas and $0.01 \%$ globally. CARPHA (2020, April 8) reiterated: "The risk of disease importation to the Caribbean Region remained Very High." Among the reasons for this risk assessment were that: 1) one member state which reported confirmed cases shares a border with another state, and 2) there were direct flights into the Caribbean from countries with sustained transmission of the COVID-19. On 8 April, there were approximately 4,000 cases in the Caribbean, of which $60 \%$ were imported and $32 \%$ were from local transmission (CARPHA, 2020, April 8). One month later, on 8 May, the case numbers had risen to approximately 15,000, with 52\% attributed to local transmission and $32 \%$ imported (CARPHA, 2020, May 8). On 12 June, the situation in the Caribbean began to change as transmissions were classified as clusters of cases (45\%), sporadic cases (39\%), community transmission (10\%), and two countries or territories reported no cases (CARPHA, 2020, June 12). However, according to CARPHA (2021, January 28), at the end of January 2021, 24 out of 35 Caribbean countries reported sporadic and community spread, with 16 of those reporting community transmission. Table 1 provides a snapshot of cases prior to- 30 June, 2020 and after- 26 January, 2021, border opening in Caribbean countries and territories.

According to Hambleton, Jeyaseelan, and Murphy, (2020, p. e111, p. e114): “In February and March, Caribbean governments, watching the COVID-19 outbreak unfold [...] and perhaps aware of their own health fragilities, acted swiftly"; and "the Caribbean response to the regional COVID-19 outbreak might be described as a network of national responses strengthened by a familiar regional support structure." In this regard, the Caribbean generally implemented containment measures much earlier than other countries such as Italy, Germany and the United Kingdom (Murphy et al, 2020; Hambleton, Jeyaseelan, \& Murphy, 2020). The Caribbean as a region was doing well with COVID-19 containment, and in this regard, Murphy et al. (2020, p. 5) noted: "As of May 25 2020, the Caribbean region had broadly achieved initial containment, with the exception of the outbreak on the island of Hispaniola." 
Table 1. Selected physical and COVID-19 information on Caribbean countries and jurisdictions. Sources: CIA World Factbook, 2020; PAHO, 2021; WHO, 2020, June 12; WHO, 2021.

\begin{tabular}{|c|c|c|c|c|c|c|c|}
\hline Islands & $\begin{array}{c}\text { Size } \\
\left(\mathbf{k m}^{2}\right)\end{array}$ & Pop. & Pop. $/ \mathbf{k m}^{2}$ & $\begin{array}{c}\text { Cases on } \\
30 / 6 / 20\end{array}$ & $\begin{array}{c}\text { Cases / } \\
100,000 \\
\text { pop. }\end{array}$ & $\begin{array}{l}\text { Cases on } \\
26 / 01 / 20\end{array}$ & $\begin{array}{c}\text { Cases / } \\
100,000 \\
\text { pop. }\end{array}$ \\
\hline Cuba & 109,820 & $11,059,062$ & 101 & 2,340 & 21 & 21,828 & 197 \\
\hline $\begin{array}{l}\text { Dominican } \\
\text { Republic }\end{array}$ & 48,320 & $10,499,707$ & 217 & 31,816 & 303 & 205,152 & 1,954 \\
\hline Haiti & 27,560 & $11,067,777$ & 402 & 5,847 & 53 & 11,286 & 102 \\
\hline Jamaica & 10,991 & $2,808,570$ & 256 & 696 & 25 & 15,012 & 535 \\
\hline Bahamas & 10,101 & 37.721 & 34 & 104 & 31 & 8,101 & 2.399 \\
\hline Puerto Rico & 8,959 & $3,189,068$ & 356 & 7,250 & 227 & 91,596 & 2,872 \\
\hline $\begin{array}{l}\text { Trinidad \& } \\
\text { Tobago }\end{array}$ & 5,128 & $1,208,789$ & 236 & 126 & 10 & 7,473 & 618 \\
\hline $\begin{array}{l}\text { Turks \& } \\
\text { Caicos }\end{array}$ & 948 & 55,926 & 59 & 41 & 73 & 1,287 & 2,301 \\
\hline Dominica & 751 & 74,243 & 99 & 18 & 24 & 113 & 152 \\
\hline St. Lucia & 606 & 166,487 & 275 & 19 & 11 & 886 & 532 \\
\hline Curacao & 444 & 151,345 & 341 & 24 & 16 & 4,548 & 3,005 \\
\hline $\begin{array}{l}\text { Antigua \& } \\
\text { Barbuda }\end{array}$ & 443 & 98,179 & 222 & 55 & 56 & 201 & 305 \\
\hline Barbados & 430 & 294,650 & 685 & 97 & 33 & 1,387 & 471 \\
\hline $\begin{array}{l}\text { St. Vincent } \\
\& \text { the } \\
\text { Grenadines }\end{array}$ & 389 & 101,390 & 261 & 29 & 29 & 746 & 736 \\
\hline USVI & 346 & 106,325 & 307 & 81 & 76 & 2,341 & 2,202 \\
\hline Grenada & 344 & 113,094 & 329 & 23 & 20 & 148 & 131 \\
\hline $\begin{array}{l}\text { Cayman } \\
\text { Islands }\end{array}$ & 264 & 61,944 & 235 & 196 & 316 & 383 & 618 \\
\hline $\begin{array}{l}\text { St. Kitts \& } \\
\text { Nevis }\end{array}$ & 261 & 53,821 & 206 & 15 & 28 & 35 & 65 \\
\hline Aruba & 180 & 119,428 & 663 & 101 & 85 & 6,723 & 5,629 \\
\hline BVI & 151 & 37,381 & 248 & 8 & 21 & 137 & 366 \\
\hline Montserrat & 102 & 5,373 & 53 & 11 & 205 & 13 & 242 \\
\hline St. Martin & 54 & 32,566 & 599 & 43 & 132 & 1,191 & 3,657 \\
\hline Bermuda & 54 & 71,750 & 1,329 & 146 & 203 & 686 & 956 \\
\hline Singapore & 709 & $6,209,660$ & 8,756 & 41,615 & 670 & 56,260 & 954 \\
\hline
\end{tabular}

However, Caribbean leaders had to address the economic fallout due to the collapse in tourism, which is the mainstay of the majority of Caribbean islands (ECLAC, 2020). As a result, border restrictions were lifted and eased by mid-2020 in most countries and territories. Coupled with the Christmas holiday, border re-openings led to a surge in COVID-19 cases: at the end of December 2020, there were 373,117 cases, and at the end of January 2021, there were 448,031 cases (CARPHA, 2021, January 28). Table 1 shows the increases in cases per 100,000 population in June 2020 compared to January 2021. Prior to border re-openings, the Caribbean was apparently doing an excellent job in keeping case numbers low and curbing the transmission and spread of COVID-19 (discussed in subsequent sections). However, this changed as the realities of economic pressures manifested. The case study island provides some more intricate insight as an example of what may have transpired in many Caribbean islands. 
Table 2. Timeline of key actions and measures to contain COVID-19 in Grenada. Sources: WHO, 2021a, 2021b; https://www.nowgrenada.com/category/press-release.

\begin{tabular}{|l|l|}
\hline Timeline & Actions and measures \\
\hline $\mathbf{1 3 / 0 3 / 2 0}$ & $\begin{array}{l}\text { Various social distancing measures implemented. In an address to the nation, } \\
\text { the Prime Minister announced additional measures, including the closure of } \\
\text { all schools, effective Monday, 16 March 2020 (Mitchell, 2020, March 13). }\end{array}$ \\
\hline $\mathbf{2 0 / 0 3 / 2 0}$ & $\begin{array}{l}\text { Announcement of various economic measures for March-May, to address } \\
\text { potential economic fallout associated with imminent closures of hotels, } \\
\text { restaurants, and other places of employment, especially for the hotel and } \\
\text { tourism sector (Mitchell, 2020, March 20). }\end{array}$ \\
\hline $\mathbf{2 2 / 0 3 / 2 0}$ & $\begin{array}{l}\text { Announcement of Grenada's first case of COVID-19, an imported case. } \\
\text { Maurice Bishop International Airport (MBIA) closed to all commercial } \\
\text { passenger traffic. Only aircraft carrying cargo and pre-approved medical } \\
\text { supplies allowed to land, as necessary. }\end{array}$ \\
\hline $\mathbf{2 5 / 0 3 / 2 0}$ & $\begin{array}{l}\text { State of emergency declared under 'Emergency Powers (COVID-19) } \\
\text { Regulations, Statutory Rules and Orders No, 13 of 2020 (SRO-13)' } \\
\text { (Mitchell, 2020, March 25). 21-day curfew imposed. }\end{array}$ \\
\hline $\mathbf{2 9 / 0 3 / 2 0}$ & $\begin{array}{l}\text { As cases began to rise, a mandatory 24-hour curfew was further imposed } \\
\text { (Steele, 2020, March 29). }\end{array}$ \\
\hline $\mathbf{0 3 / 0 4 / 2 0}$ & $\begin{array}{l}\text { Concern expressed over breaches of rules: "While we have allowed limited } \\
\text { grocery shopping and other access to services, we continue to see breaches of } \\
\text { social distancing, and the curfew, in general" (Steele, 2020, April 3). }\end{array}$ \\
\hline $\mathbf{0 6 / 0 4 / 2 0}$ & $\begin{array}{l}\text { 24-hour curfew extended to 20 April 2020 } \\
\text { Minister of Health proudly announced that there was only one active case of } \\
\text { COVID in Grenada (Steele, 2020, June 5). }\end{array}$ \\
\hline $\mathbf{0 5 / 0 6 / 2 0}$ & $\begin{array}{l}\text { Restrictions lifted on commercial passenger travel. } \\
\text { A cluster of 26 cases, including employees and guests, linked to a hotel. } \\
\text { to operate in October. }\end{array}$ \\
\hline $\mathbf{2 7 / 1 2 / 2 0}$ & $\begin{array}{l}\text { } 116 \text { active cases announced. } \\
\text { restrictions on gatherings, and a reduced curfew put in place. }\end{array}$ \\
\hline $\mathbf{0 1 2 / 2 0}$
\end{tabular}

\section{Grenada's measures to curb COVID-19 transmission}

The tri-island state of Grenada, Carriacou and Petite Martinique is located by the coordinates of the larger island Grenada at $\sim 12 \mathrm{deg}$. $\mathrm{N}$ and $\sim 62 \mathrm{deg}$. W. The population of all the islands is about 110,000 , living on a total of $344 \mathrm{~km}^{2}$ of mountainous land. This translates to a population density of about 320 persons per $\mathrm{km}^{2}$. Grenada's economy is built on services, which account for about $73 \%$ of GDP; with a high reliance on tourism. The connection between the islands is via sea and air, with daily ferry transportation and flights to Carriacou. 
One ferry has the capacity to move persons and their vehicles to and from Carriacou. A number of small schooners support the transport of goods between Grenada to Carriacou on a weekly basis. There is a robust connection between the smaller islands of Grenada and those of St. Vincent and the Grenadines. This link presents an important geo-political relationship (Grydehøj. Kelman, \& Su, 2020) between the independent states of Grenada and St. Vincent, which is discussed in the section on the archipelagic intrigue. Table 2 provides a chronicle of key events and actions taken by Grenada to mitigate the spread of COVID-19.

In sum, the government of Grenada, like most Caribbean governments, began with social distancing and other internal restrictions, before border closures and controls were implemented. All borders in the Caribbean remain open as of January 2021, but internal restrictions are still enforced, in an effort to contain the spread of COVID-19, a situation that exists in many other Caribbean islands.

\section{Illuminating the notions of islandness: Were islands immune?}

The Caribbean region experienced relative success with mitigation of COVID-19 spread. To some extent, the notions of spatial islandness and their combinations may have contributed to that success. Drawing on the case of Grenada and other comparative examples, islandness from that perspective is interrogated.

\section{Celebrating boundedness, but...}

The marked boundaries of islands allow for more effective border control on islands. It is no wonder then that, as COVID-19 escalated globally, an easily manageable strategy was to close the formal borders. In the case of Grenada, the border was 'partially' closed on 22 March 2020, the same day the first COVID-19 case was announced. Grenada's border was open to cargo and other entries for emergencies. Generally, sixteen out of twenty Caribbean islands implemented full border closures (Murphy et al, 2020), and "national measures to restrict movement into Caribbean countries were implemented up to 27 days before the first confirmed case" compared to 23 days in other countries outside the region (Hambleton, Jeyaseelan and Murphy, 2020, p. e114). Figures 2(a) and 2(b), demonstrate the fluctuation in monthly cases for Grenada and the Bahamas. The Bahamas opened its border on 1 July 2020, resulting in spikes, and placed restrictions on some inbound flights on 22 July. For Grenada, the airport was reopened in August 2020, resulting in a spike in cases in December from a tourist resort (see Table 2) post border reopening.

Once the formal border entry points were closed or restricted, Grenada and other Caribbean islands were somewhat sealed off from outsiders who might come bearing the SARS-CoV-2 virus. Figures 2(a) and 2(b) show the relatively stable average daily cases in Grenada prior to August 2020 and July 2020 in the Bahamas as well as the spikes post-border openings. Island border controls are more easily implemented and managed as they are lesser in number and generally smaller in nature. But due to the lack of manpower and institutional capacity, illegal entry may occur. In this regard, and specifically in the corona crisis, residents who live on the coast pay keen attention to incoming ships, yachts and boats, which may be bringing any such intruders or possible suspect cases of COVID-19 and may alert the authorities about breaches in security. In a press release on 14 July 2020, Straker (2020, July 
20) recorded a statement from a government official: "We have had attempts of individuals entering the country without going through the normal channels."

(a)

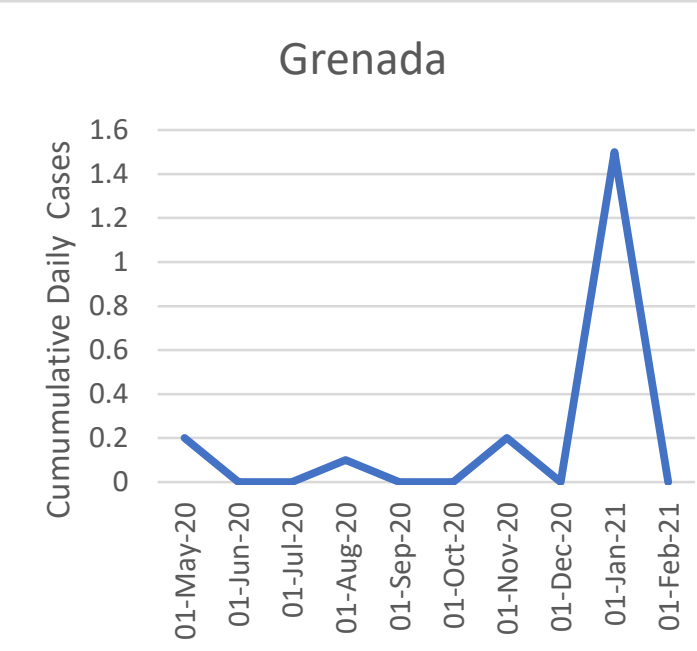

(b)

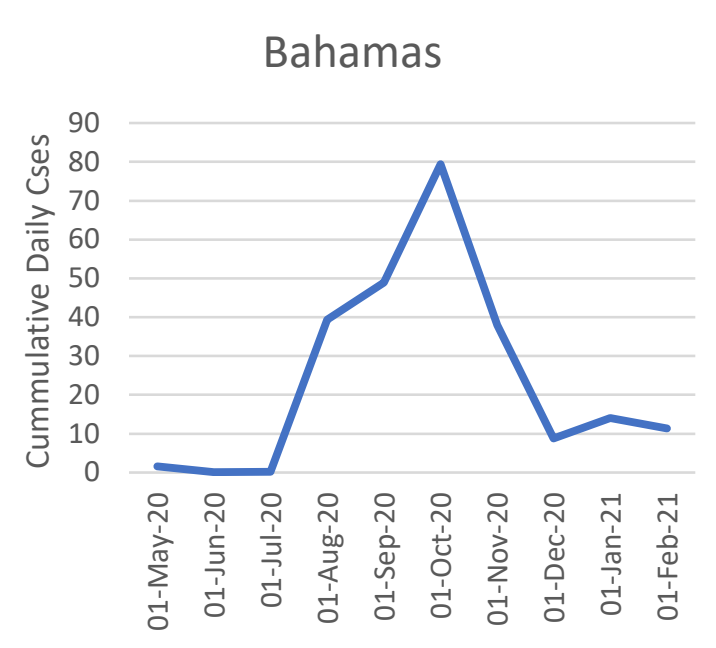

Figure 1. Trends in daily cases for (a) Grenada and (b) the Bahamas. Data source: Orr, 2021.

In the main, however, the border closures did assist with reducing caseloads on islands, especially in the early stages for the Caribbean islands (see Table 1, cases 20/06/20). However, this celebration may have been temporary as island authorities grappled with the re-opening of borders, to support the high dependence on tourism for economic growth. According to the Prime Minister of Grenada, in a national address (Mitchell, 2020, June 28): "Many are wishing we can remain in the protective bubble that has kept us safe since March and that we can maintain the COVID-free status announced earlier this month. However, this is not a practical, long term option."

The majority of Caribbean countries re-opened their borders in July/August 2020, and with it the cases began to rise in all countries (see Table 1, cases 26/01/21). However, in countries that did not close their borders early on, increases were much higher, as in Barbados and St. Vincent, where cases per 100k population grew by 45 and 27 times respectively.

Border closures and controls can serve as a valve that can simultaneously import tourists to restart and boost the economy, while hopefully not bringing in COVID-19. But as the Prime Minister of Grenada said, the Caribbean cannot continue to live in a bubble, and therefore the need to begin to live with the realities of COVID-19 must be taken seriously. In this regard, controls at the border that require passengers to present a COVID-19 test result, implementation of NPIs such as the wearing of masks and physical distancing, and now vaccinations which have been introduced in many Caribbean islands will continue to mitigate spread. Boundedness can be celebrated, but this was only temporary. However, this measure of border closures, which may serve to slow the spread of COVID-19, is still available if a similar pandemic occurs in the future. Filho et el. (2020, p. 4) conclude: "Countries that closed their borders to tourists and other travelers and required citizens to quarantine achieved some level of success in reducing or preventing transmission" of the disease. 


\section{Is isolation still relevant?}

Isolation may have prevented the spread of COVID-19 in some islands. For example, Orr (2021) notes that: Niue, St. Helena, Ascension and Tristan da Cunha and Pitcairn, some of the most remote islands (Woodman, 2018), were COVID-19 free on 24 February 2021. Notwithstanding this, the combined physical isolation and relative connectedness of many islands to mainlands and other islands may have mitigated and/or aided the spread of COVID19 in islands. From this perspective, connectivity and more specifically access to an island by air, especially in the Caribbean, would have contributed to the entrance of COVID-19 into the majority of countries. The first case of COVID-19 was imported into the Caribbean region on 1 March 2020 which was less than two months after the first case outside of China was reported in Thailand on 13 January 2020 and subsequently in the USA on 20 January 2020. On 8 April 2020, CARPHA further reported that $62 \%$ of the 4000 cases in the Caribbean were imported. Grenada reported its first case on 21 March 2020, an imported case from the United Kingdom (see Table 2). Filho, Lütz, Sattler, and Nunn (2020, p. 3), in a study conducted on Pacific SIDS, were able to establish a positive correlation between connectivity and spread of COVID-19, "suggesting that the continued entry of people [mostly by air] was a significant factor of spread within country." Similarly, the numbers of daily cases in Grenada and the Bahamas (see Figure 2) may also be interpreted from a connectivity perspective. In this regard, the Bahamas, which attracts many more tourists and visitors than Grenada, and with many more flights, showed a higher number of cases per day.

However, island authorities relish the need for connectedness, especially as it relates to economic growth and development. The Caribbean is known to be highly dependent on travel and tourism for its economic progress, and connectivity to the source markets, mainly the USA and UK, is critical for supporting tourism. In this regard, isolation and connectedness form two sides of the same coin when it comes to COVID-19 spread. On one hand, connectedness serves to support economic growth, while on the other hand, isolation can serve as a buffer to importing the disease. In Grenada, when the borders were closed to visitors and residents leaving or entering, the authorities ensured that the air and sea ports remained opened and connected to receive goods and medical supplies.

Considering the case of Greenland, which enacted strict border closures and internal restrictions and has subsequently been free from the spread of COVID-19, Grydehøj, Kelman and $\mathrm{Su}(2020$, p. 3) ask "whether island status really does have any particular effect on the presence and prevalence of infectious disease," noting that "While it could be argued that island isolation slows the arrival of the coronavirus, it would be premature to conclude that islands are generally safer from infectious diseases than non-islands.” The authors' conclusion as it relates to isolation may be correct, for in this highly connected world of which islands are an integral part, not many islands are insulated from COVID-19. Orr concludes that only seven island countries, mainly in the Pacific have been speared the COVID-19 disease. There is a caveat here though, if islands within archipelagos, such as Grenada, Carriacou and Petite Martinique were treated as sperate islands, then Carriacou and Petite Martinique did not record any cases. The extent to which this is related to another aspect of islandness, fragmentation, will be discussed in a subsequent section. 
Does smallness really matter?

The intimate interaction found on islands may be supported by the relatively higher population densities which may be associated with islands. Baldacchino (2010, p 168) noted that, compared to continents and excluding Greenland (which, based on one's perspective, can be considered the world's largest island), the average population density of an island is three times higher than that of a continent. Using this as a proxy of 'smallness', and considering the close-knit societies found on islands, we postulated that 'smaller' islands within the Caribbean, might have higher caseloads, measured by cases per 100,000 population (see Table 1) than the 'small' islands (we chose to use small and smaller as opposed to small and large, since small is the relative word). Using a scatter plot, see Figure 2, to investigate this position, we visualize where these 'smaller' and 'small' islands fit on the 'population density/cases per 100,000 population' grid (data from table 1).

The first seven islands in Table 1, which are considered 'small' are all in the lower/left side of the scatter plot, suggesting that they have relatively lower caseloads and population densities. Conversely, of the so-called 'smaller' islands, the majority also appear in the lower/left quadrant, with some notable exceptions: Aruba and St. Martin, which are in the upper left portion with relatively high caseloads and population densities. The smallest of all the islands Bermuda, appears at the upper left of the grid, with high cases loads and population density.

Although this approach does not prove that high population densities result in or cause higher caseloads, it does provide a comparative visual of how COVID-19 spreads in small and smaller islands. Additionally, the analysis did not take into consideration the timing of border closures, the nature and stringency of the measures implemented by the various islands, and other health-related aspects, such as the abilities of these islands to test, trace and isolate and the robustness of an island's health system, which will all have a profound impact on case numbers. However, one of the 'smaller' global SIDS, Singapore, which may have a robust health system and one of the highest population densities in the world, also has one of the highest caseloads per 100,000 population among islands (see Table 1). Additionally, we are not aware of any consensus on what is a 'high' or 'low' population density, but if the average proposed by Baldacchino (2010) of $144 \mathrm{~km}^{2}$ is used as a baseline, only five of the Caribbean islands have population densities below the base. Of these, two islands- Cuba and the Bahamas are in the so-called 'small' islands category.

Smallness, exacerbated by islands' relatively high population densities, may possibility enhance the spread of the COVID-19. According to Filho et al. (2020, p. 4), "Many islands are densely populated and have inadequate sanitation [...], providing fertile contextual conditions for both the spread of infection and its entrapment." Locked into closely knitted communities, usually on the coast, there may be no place to escape from the virus. Islands, especially CSIDS, have so far done extremely well in curbing the transmission and spread of COVID-19 and keeping case numbers relatively low. However, the issue of smallness and intimacy on islands should be kept in focus by island leaders as many islands in the Caribbean are now experiencing community spread, making 'smallness' matter.

\section{The archipelagic intrigue: Fragmentation in the Caribbean}

The Caribbean region has long been considered an archipelago, arching from Trinidad and Tobago in the south and north of the South American continent to the Bahamas and Cuba in the northwest and south of the North American continent. But the region can also be 
described as a number of 'archipelagos within the archipelago'. The key sub-groups of archipelagos include: in the Caribbean Sea and north of the South American mainland, the Leeward Antilles (formally Netherland Antilles); the Greater Antilles, forming the northern ach and the largest islands; the Windward Islands and Lesser Antilles (see e.g. Thompson, Downer-Lawson, St. John, \& Hunte-Thomas, 2017). However, within these sub-groups are further sub-groups of a number of self-governing and autonomous islands, with a central island as the mainland. Examples of these include: Trinidad and Tobago; Grenada, Carriacou and Petite Martinique; St. Vincent and the Grenadines; Antigua and Barbuda; St. Kitts and Nevis; and the Bahamas.

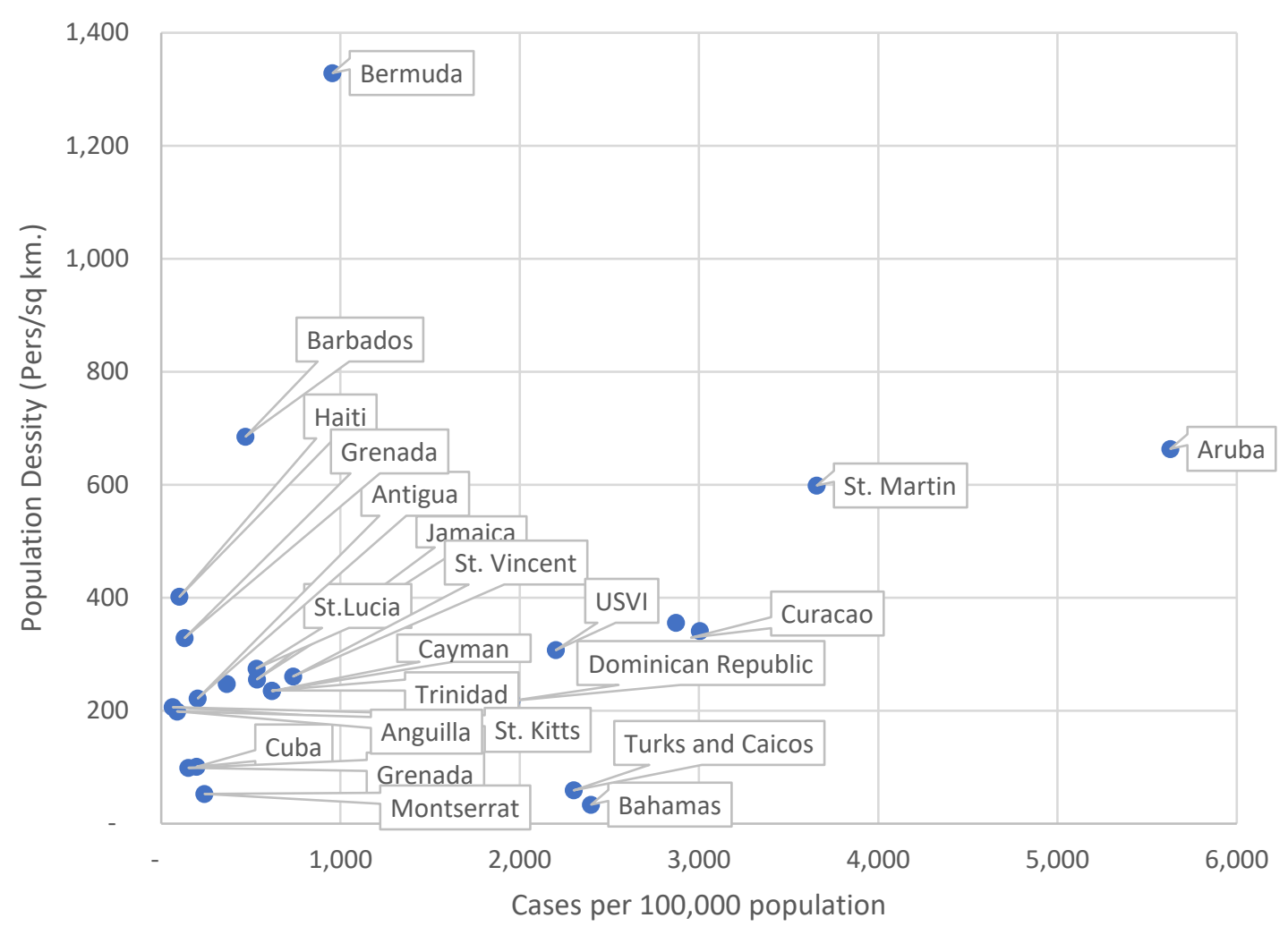

Figure 2. Grid of population densities versus caseloads per 100,000 population of CSIDS. Sources: CIA World Factbook, 2020; PAHO, 2021; WHO, 2020, June 12; WHO, 2021.

This fragmentation of the Caribbean into a 'group of islands' or archipelagos epitomizes, "The concept of the archipelago [which] foregrounds interactions between and among islands themselves. The relation of island to island is characterized by repetition and assorted multiplicity, which intensify and disrupt relations of land and water, as well as island and continent/mainland" (Baldacchino, 2018, p. xxiv).

The case study is an archipelago consisting of Grenada, Carriacou and Petite Martinique, located in the Windward Islands, which is in extremely close proximity to the archipelagic islands of St. Vincent and the Grenadines. As COVID-19 found its way into the Caribbean, including Grenada and St. Vincent, the islands' authorities responded differently in terms of applying border closures and controls and internal NPIs, sparking inter- and intraisland tensions. Firstly, the interactions between Grenada and its smaller sister isles was strained 
on a few fronts: trade between the islands, the issue of medical supplies and testing and the halting of domestic travel via air and sea. Trade between the islands was disrupted, especially during the period of the 24/7 curfew. Shopkeepers, business persons and consumers began to clamor for food, petrol, cooking gas and other items that were traded between the islands. As the first case was confirmed on the island of Grenada, the residents of Carriacou and Petite Martinique, became very guarded of their shores, ensuring that suspected COVID-19 infected Grenadians or foreign visitors stayed away. However, it soon became apparent that it was necessary for the residents of Carriacou and Petite Martinique to travel to Grenada, so the call for limited passenger travel between the islands soon emerged. This juggle of attempting to prevent the entrance of COVID-19 into the islands of Carriacou and Petite Martinique and the need to maintain a connection between the smaller islands and Grenada shored up the archipelagic intrigue of 'central island, smaller island' dependency. Another key example, was the brief squabble between the islands, as Carriacou called for medical supplies and equipment, especially, ventilators, to be installed in the hospital on the island. However, the authorities pushed back and prevailed, countering that fast transportation to Grenada was the more economical option if the need arose.

Additionally, as Grenada strived to contain its COVID-19 spread, more intrigue with the intra-island relationship sprung-up, when the 24/7 curfew was imposed on Grenada, Carriacou and Petite Martinique, and at the same time the borders of neighboring St. Vincent and the Grenadines were still partially open. Moreover, as average daily caseloads rose in St. Vincent in January 2021 to 45, while Grenada remained at zero, the Grenada government took precautionary measures to prevent spread into the islands of Carriacou and Petite Martinique by deploying border security measures in Carriacou. From a historical and author's perspective, the relationship between the 'smaller' islands of the Grenadines and those of Grenada may be described as close knit, due mainly to fishing and small-scale trade. With speed boats, which proliferate the smaller island space, interaction between Carriacou, Petite Martinique and the Grenadine islands is more intertwined than between these islands and their larger islands. I have personally visited these islands and had the opportunity, although for leisure, to experience the speed and ease with which one can travel from Grenada's territory to St. Vincent's territory. It was analogous to hopping into a car to get to your destination, thus exacerbating the possibility of COVID-19 spread between these independent islands. As a consequence, the Prime Ministers of these two countries traded words (Straker, 2020, April 11) that highlighted the island/island interactions and the tensions that these intricate connections can cause, as these independent states institute differing COVID-19 containment measures. As Grydehøj, Kelman and Su (2020, p. 3) conclude, intra-archipelago, island-island, and island-mainland geopolitics can all be "affected by infectious disease."

\section{Conclusions and potential research post-COVID-19}

As demonstrated in the Caribbean region, the spatial notions of islandness may have provided some immunity to islands against COVID-19 in the early stages of the pandemic. Boundedness would have given islands the ability to have more comprehensive control over travel via air and sea. This may have prevented high caseloads on the islands, especially in Grenada and other Caribbean islands. However, border closures and controls may have also been temporary, as creating the 'island bubble' was not a realistic prospect, as Caribbean 
islands in particular are dependent on travel and tourism for economic growth and development. Therefore, the reopening of borders was inevitable, and this happened as the corona crisis continued to spread worldwide. But compared to contiguous landmasses, with other land borders, islands may have more control over border entries, and as such can effectively use border opening and closing as a control valve to mitigate and suppress the spread of COVID-19 importation and caseloads.

Although some islands have managed to fend off COVID-19 due to their relative isolation, many islands are hardly isolated. In fact, Caribbean islands are very connected via air and sea, to the North and South American mainland and to other islands. Therefore, the notion of isolation and concomitantly connectedness, based on the close proximity of island to mainland and island to island, may have only delayed the importation of the COVID-19 into Caribbean islands and other islands, such as those in the Pacific. Specially, the majority of COVID-19 cases in the Caribbean came from source markets, such as the USA and UK, from which significant numbers of tourists travel and from which a high number of naturalized Caribbean citizens travel into the Caribbean relatively easily.

COVID-19 eventually came to the islands, and island authorities had to deal with internal mitigation and spread. Smallness may be emerging as having played a role in this spread, although effective NPIs, such social distancing measures, internal travel restriction and reduced gatherings may have contributed more significantly. A tentative look at the caseloads, population densities, and physical sizes of the islands highlighted that smaller islands with high population densities are generally characterized by a higher number of cases per 100k population. Although there is no correlation between the two, island authorities must remain mindful that the intricate interaction between the populations and the delicate nature of island health systems mean that smallness can play a significant role in the spread or containment of COVID-19 on islands, especially in the instances of community spread. This is a key observation that can be further investigated in the future.

Island-island relations, central island-other island relations also came into focus as border controls tightened at varying scales in the Caribbean region. The interesting, but apparently short-lived feud between St. Vincent and the Grenadines on the one hand and Grenada, Carriacou and Petite Martinique on the other illuminated relationships and nuances that are very much present in archipelagic islands. As cases rose on the so-called 'main island' of Grenada, the smaller isles raised concerns regarding spread into the smaller islands, but with consideration for maintaining trade in goods between the islands. Additionally, as caseloads escalated in St. Vincent faster than in Grenada, and with less stringent border controls in the former, the need to contain the spread of the virus in Grenada and to prevent the entrance into the islands of Carriacou and Petite Martinique intensified geopolitical tensions with this archipelagic region.

Islands may have a tremendous opportunity to serve as laboratories for studying the SARS-CoV-2 and the spread of COVID-19 disease. Island epidemiology has been researched and provided insight into contagious diseases in the past (e.g. Cliff, Haggett, \& SmallmanRaynor, 2007). As many islands, including in the Caribbean, boast high-quality public health institutions and collaborations with global and regional organizations, such research can become possible. For example, the St. George's University in Grenada, has established “a state-of-the-art diagnostic molecular facility [...] that will also be a resource for faculty and students to conduct research" (Mauser, 2021). Additionally, research into the social impacts, effects, and relationships involving variables such as smallness, boundedness, isolation and 
fragmentation form themes for further research. Additionally, research on islander's perceptions and feeling of been on an island during the crisis can also add to the rich discourse on islandness (see for example Baldacchino, 2005).

In conclusion, islandness, characterized by the spatial variables and their combinations and permutations, was illuminated and may have temporarily provided immunity or delayed the spread of COVID-19 on islands, especially in Caribbean islands. In this regard, for the world of islands, which are permanently integrated into the globe and connected, interrogating the spatial notions of islandness in the context of global issues such as pandemics will become more important as we move into the future.

\section{References}

Andrus, J. K., Evans-Gilbert, T., Santos, J. I., Guzman, M. G., Rosenthal, P. J., Toscano, C., Valenzuela, M. T., Siquaina, M., Etienne, C., \& Breman, J. G. (2020). Perspectives on battling COVID-19 in countries of Latin America and the Caribbean. The American Journal of Tropical Medicine and Hygiene, 103(2), 593-596. https://doi.org/10.4269/ajtmh.20-0571

Baldacchino, G. (2020). How it feels 'on the ground': The experiences of residents from a subnational island jurisdiction. Small States and Territories, 3(1), 123-136.

Baldacchino, G. (2018). Preface. In G. Baldacchino (Ed), The Routledge international handbook of Island Studies: A World of Islands (pp. xix-xxxv). Routledge.

Baldacchino, G. (Ed.) (2015). Archipelago tourism: Policies and practices. Ashgate.

Baldacchino, G. (2013). Competing notions of diversity in archipelago tourism: Transport logistics, official rhetoric and inter island rivalry in the Azores. Island Studies Journal, 8(1), 84-104.

Baldacchino, G. (2010). Island enclaves: Offshoring strategies, creative governance, and subnational island jurisdictions. McGill-Queens University Press.

Baldacchino, B. (2005). Editorial: Islands: Objects of representation. Geografiska Annaler, Series B, Human Geography, 87(4), 247-251.

CARPHA (2020, March 4). Situation report \#18. Caribbean Public Health Agency.

CARPHA (2020, March 20). Situation report \#21. Caribbean Public Health Agency.

CARPHA (2020, April 8). Situation report \#32. Caribbean Public Health Agency.

CARPHA (2020, May 8). Situation report \#43. Caribbean Public Health Agency.

CARPHA (2020, June 12). Situation report \#57. Caribbean Public Health Agency.

CARPHA (2021, January 28). Situation report \#127. Caribbean Public Health Agency.

Cliff, A., Haggett. P., \& Smallman-Raynor, M. (2007). Island epidemiology. In G. Baldacchino (Ed.), A world of islands (pp. 267-291). Institute of Island Studies \& Agenda Academic.

ECDC (2020). Considerations for relating to social distancing measure in response to the COVID-19 pandemic. European Centre for Diseases Control and Prevention.

ECLAC (2020). Report on the economic impact of coronavirus disease (COVID-19) on Latin America and the Caribbean. Economic Commission for Latin America and the Caribbean, United Nations.

Escobedo, A. A., Rodríquez-Morales, A. J., Almirall. P., Almanza, C., \& Rambaut, R. (2020). SARS-CoV-2/COVID-19: Evolution in the Caribbean islands. Travel Medicine and Infectious Disease, 37, 101854. https://doi.org/10.1016/j.tmaid.2020.101854 
Ferguson, N.M., Laydon, D., Nedjati-Gilani, G., Imai, N., Ainslie, K., Baguelin, M., Bhatia, S., Booyasiri, A., Cucunubá, Z., Cuomo-Dannenburg, G., Dighe, A., Dorigatti, I., Fu, H., Gaythrope, K., Green, W., Hamlet, A., Hinsley, W., Okell, L. C., van Elsland, S., Thompson, H., Verity, R., Volz, R., Wang, H., Wang, Y., Walker, P. GT., Walters, C., Winskill, P., Whittaker, C., Donnelly, C. A., Riley, S., \& Ghani, A. C. (2020). Impact of non-pharmaceutical interventions (NPIs) to reduce COVID-19 mortality and health demand. Imperial College COVID Response Team. https://doi.org/10.25561/77482

Filho, W. L., Lütz, J. M., Sattler, D. N., and Nunn, P. D. (2020). Coronavirus: COVID-19 transmission in Pacific Small Island Developing States. International Journal of Environmental Research and Public Health, 17, 1509, Retrieved: http://dx.doi.org/10.3390/ijerph17155409

Gourinchas, P-O. (2020). Flattening the pandemic and recession curve. In Baldwin, R. and di Mauro, B. W. (Eds). Mitigating the COVID economic crisis: Act fast and do whatever it takes (pp. 31-40). London, UK: CPRC Press.

Grydehøj, A., Kelman, I. and Su, P. (2020). Island geographies of separation and cohesion: The coronavirus (COVID-19) pandemic and the geopolitics of Kalaallit Nunaat (Greenland). Tijdschrift voor Economische en Sociale Geografie, 11(3), 288-301. https://www.doi.org/10.1111/tesg.12423

Hambleton, I., Jayaseelan, S. L. and Murphy, M. M. (2020). COVID-19 in the Caribbean Small Island Developing States: Lessons learnt from extreme weather events. The Lancet, 8(9), E1114-E1115. https://doi.org/10.1016/S2214-109X(20)30291-6

Hay, P. (2006). A phenomenology of islands. Island Studies Journal, 1(1), 19-42,

Mauser, B. (2021, February 25). New on-campus lab strengthens diagnostics, education and research in Grenada. St. George's University. https://www.sgu.edu/news-andevents/new-on-campus-lab-strengthens-diagnostics-education-and-research-in-grenada/

Mitchell, K. (2020, March 13). Prime Minister's national address on COVID-19. NOW Grenada. https://www.nowgrenada.com/2020/03/prime-ministers-address-on-covid-19/

Mitchell, K. (2020, March 20). Prime Minister's national address. NOW Grenada. https://www.nowgrenada.com/2020/03/prime-ministers-national-address-20-mar-2020/

Mitchell, K. (2020, March 25). Announcement of limited state of emergency at a national address by Dr. the Right Hon. Keith Mitchell, Prime Minister, Grenada. NOW Grenada. https://www.nowgrenada.com/2020/03/announcement-of-limited-state-of-emergency/

Mitchell, K. (2020, June 28). National address by Dr. the Rt. Hon. Keith Mitchell. NOW Grenada. https://www.nowgrenada.com/2020/06/national-address-by-dr-the-rt-honkeith-mitchell//

Murphy, M. M., Jeyaseelan, S. M., Howitt, C., Greaves, N., Harewood, H., Quimby, K. R., Sobers, N., Landis, R. C., Rocke, K. D., \& Hambleton, L. R. (2020). COVID-19 containment in the Caribbean: The experience of small island developing states. Research in Globalization, 2, 100019. https://doi.org/10.1016/j.resglo.2020.100019

Orr, I. (2021). COVID-19 and islands (States, Territories and Sub-national Island Jurisdictions- SNIJs). International Small Island Studies Association.

PAHO (2021, January 26) Cumulative confirmed and probable cases reported by Countries and Territories in the Region of the Americas. Pan-American Heath Organization. 
Pugh, J. (2013). Island movements: Thinking with the Archipelago. Island Studies Journal, $8(1), 9-24$.

Randall, J. (2021). An introduction to island studies. Rowman and Littlefield.

Royle, S., \& Brinklow, L. (2018). Definitions and typologies. In G. Baldacchino (Ed), The Routledge international handbook of Island Studies: A World of Islands (pp. 3-20). Routledge.

Sheller, M. (2020). Reconstructing tourism in the Caribbean: Connecting pandemic recovery, climate resilience and sustainable tourism through mobility justice. Journal of Sustainable Tourism. https://doi.org/10.1080/09669582.2020.1791141

Steele, N. (2020, March 29). Address by Minister of Health, Hon. Nikolas Steele. NOW Grenada. https://www.nowgrenada.com/2020/03/address-by-minister-for-healthhon-nickolas-steele/

Steele, N. (2020, April 3). COVID-19 update by Minister of Health. NOW Grenada. https://www.nowgrenada.com/2020/04/covid-19-update-by-nickolas-steeleminister-for-health/

Straker, L. (2020, April 11). PM Mitchell labels PM Gonsalves' food shopping invitation as irresponsible. NOW Grenada. https://www.nowgrenada.com/2020/04/pm-mitchelllabels-pm-gonsalves-food-shopping-invitation-as-irresponsible/

Steele, N. (2020, June 5). COVID-19 update statement 5 June, 2020. NOW Grenada. https://www.nowgrenada.com/2020/06/covid-19-update-statement-5-june-2020/

Straker, L. (2020, July 20). Yacht caught attempting to illegal enter Grenada. NOW Grenada. https://www.nowgrenada.com/2020/07/yacht-caught-attempting-to-illegally-enter-grenada

Stratford, E., Baldacchino, G., McMahon, E. Farbotko, C. and Harwood, A. (2011). Envisioning the archipelago. Island Studies Journal, 6(2), 113-130.

Thompson, K., Downer-Lawson, M., St. John, A., \& Hunte-Thomas, E. (2017). CAPE revision guide: Caribbean studies. Harper-Collins.

Woodman, S. (2018). Welcome to the 11 most remote islands in the World. The culture trip. https://theculturetrip.com/north-america/mexico/articles/welcome-to-the-11-mostremote-islands-in-the-world/

WHO (2021). COVID-19 weekly epidemiological update. https://www.who.int/publications/m/item/weekly-epidemiological-update---2february-2021

WHO (2020, March 11). Press Release: WHO Director-General's opening remarks at media briefing on COVID-19- 11 March, 2020. World Health Organization. https://www.who.int/dg/speeches/detail/who-director-general-s-opening-remarksat-the-media-briefing-on-covid-19---11-march-2020

WHO (2020, June 12). Situation Report \#: 144 on 12 June, 2020. https://www.who.int/docs/default-source/coronaviruse/situation-reports/20200612covid-19-sitrep-144.pdf?.sfvrsn=66ff9f $4 \mathrm{f} 4$

WTTC (2020). To recovery and beyond: The future of travel and tourism in the wake of COVID-19. World Travel and Tourism Council.

WTTC (2018). Travel and tourism economic impact 2018: Caribbean. World Travel and Tourism Council. 